\title{
Mechanisms of antibacterial activity and stability of silver nanoparticles grown on magnetron sputtered $\mathrm{TiO}_{2}$ coatings
}

\author{
K ZAWADZKA ${ }^{1}$, A KISIELEWSKA ${ }^{2}$, I PIWOŃSKI ${ }^{2}$, K KA¿DZIOŁA ${ }^{2}$, A FELCZAK ${ }^{1}$, \\ S RÓŻALSKA ${ }^{1}$, N WROŃSKA ${ }^{1}$ and K LISOWSKA ${ }^{1, *}$ \\ ${ }^{1}$ University of Lodz, Faculty of Biology and Environmental Protection, Department of Industrial Microbiology \\ and Biotechnology, Banacha 12/16, 90-237 Lodz, Poland \\ ${ }^{2}$ University of Lodz, Faculty of Chemistry, Department of Materials Technology and Chemistry, \\ Pomorska 163, 90-236 Lodz, Poland
}

MS received 31 July 2015; accepted 14 September 2015

\begin{abstract}
Nanomaterials with high stability and efficient antibacterial activity are of considerable interest. The preparation of silver nanoparticles (AgNPs) on titania coatings and their effective antibacterial activity against Staphylococcus aureus ATCC 6538 were reported. Titanium dioxide $\left(\mathrm{TiO}_{2}\right)$ coatings with AgNPs were prepared on $\mathrm{Si}$ wafers using the reactive magnetron sputtering method. The surface topography of $\mathrm{AgNPs} / \mathrm{TiO}_{2}$ coatings imaged using scanning electron microscopy revealed that the size and surface density of AgNPs grown by the photoreduction of silver ions were dependent on the concentration of $\mathrm{AgNO}_{3}$ in the primary solution and the time of $\mathrm{TiO}_{2}$ exposure to UV illumination. Evaluation of the antimicrobial properties and surface analysis before and after the biological test of $\mathrm{AgNPs} / \mathrm{TiO}_{2}$ coatings indicates their high antimicrobial stability and durability. Furthermore, the interdependence between the concentration of released silver and bacterial growth inhibition was demonstrated. In addition, direct contact killing and released silver-mediated killing have been proposed as a bactericidal mechanism of action of tested coatings with AgNPs.
\end{abstract}

Keywords. Silver nanoparticles; titanium dioxide; SEM; mechanism of action; antimicrobial activity.

\section{Introduction}

Nanosilver has unique physicochemical and antimicrobial properties making it the most commonly used nanomaterial in healthcare. Bacterial infections caused by microorganisms colonizing biomedical devices are a serious problem of public health care [1-3]. For these reasons, metal nanoparticles (NPs) are proposed as a covering for medical instruments and devices [4]. Owing to their antibacterial activity, silver nanoparticles (AgNPs) have found a new application as an addition in food packaging and fabrics [5,6]. Literature data demonstrated high potential of AgNPs against Gram-positive and Gram-negative bacteria. Moreover, antiviral and antifungal properties of nanosilver were showed [6-12]. In recent times, many studies of the antimicrobial activity of silverdoped titanium dioxide $\left(\mathrm{TiO}_{2}\right)$ nanocomposites have been performed $[8,9,13-16]$. $\mathrm{TiO}_{2}$ has been widely applied as a coating because of its high photoactivity, non-toxicity and strong self-cleaning properties $[10,17,18]$. Liu et al proved that mesoporous $\mathrm{Ag} / \mathrm{TiO}_{2}$ films are promising nanomaterials in self-cleaning and antimicrobial technologies because of their significant antimicrobial potential against Gramnegative bacteria Escherichia coli [8]. The high effectiveness

\footnotetext{
*Author for correspondence (katalis@ biol.uni.lodz.pl)
}

against $E$. coli was showed by $\mathrm{TiO}_{2}$ powder modified with AgNPs [9,14]. Necula and co-workers synthesized porous $\mathrm{Ag} / \mathrm{TiO}_{2}$ composite layers and investigated their activity against methicillin-resistant Staphylococcus aureus [10]. Piwoński et al [16] demonstrated the antibacterial potential of photoinducted AgNPs with a different NP diameter and their surface density on titania coatings against $S$. aureus bacteria. In another report, the antibacterial properties of Agdoped $\mathrm{TiO}_{2}$ nanosheet films against $S$. aureus and E. coli in the dark and with UV irradiation were compared [15].

Antimicrobial activity of AgNPs is determined by different factors, such as size, shape and stability of NPs. AgNPs with smaller particle size have a tendency to higher antimicrobial properties due to a larger number of atoms on the surface which are available to contact with bacterial cells or a higher amount of released $\mathrm{Ag}^{+}$ions [19]. The correlation between sizes of AgNPs, quantities of released $\mathrm{Ag}^{+}$ions and their bactericidal activity was showed by Xiu et al [7]. The shape of AgNPs also affects their toxicity towards microorganisms. A stronger antibacterial activity was showed by truncated triangular AgNPs than by NPs with a spherical and rod shape. The presence of salt, organic matter or complexing agents may condition AgNPs potential against microorganisms by influencing to their dissolution and re-precipitation. High AgNPs stability is another factor affecting their high antimicrobial properties. Non-stable AgNPs may aggregate, 
which results in a decrease in their surface area and density of $\mathrm{Ag}$ atoms on their surfaces [19].

The mechanisms of AgNPs antimicrobial activity remain not completely explained. There is a debate on the mode of bactericidal action of AgNPs and both contact killing and/or ion-mediated killing have been proposed [20].

In this study, an attempt was made to evaluate of antimicrobial properties of AgNPs on the $\mathrm{TiO}_{2}$ coatings prepared by the reactive magnetron sputtering method, which could emerge as a promising antibacterial material against a Grampositive strain of $S$. aureus. This is of clinical interest because these bacteria are a common human pathogen, which can cause a wide variety of diseases from skin and wound infections to serious life-threatening conditions like pneumonia, endocarditis and bacteraemia $[21,22]$. An ideal antimicrobial material should act both through a release of an antimicrobial agent and a direct contact-killing mechanism [20]. Therefore, mechanisms of the antibacterial action of the tested coatings were studied using confocal and scanning electron microscopy (SEM) combined with silver release analyses using atomic absorption spectrometry (AAS). The use of coatings with AgNPs for practical application requires determination of their antimicrobial potential as well as their stability and durability. Therefore, the study was focused on the evaluation of the antimicrobial stability and durability of AgNPs/ $/ \mathrm{TiO}_{2}$ coatings by providing their microscopic images and their surface analysis before and after biological tests.

\section{Experimental}

\subsection{Materials}

Single side polished silicon $\mathrm{Si}(100)$ wafers used as substrates for $\mathrm{TiO}_{2}$ coatings were purchased from Cemat Silicon S.A. Poland. Silver nitrate (POCH, pure, $99.8 \%$ ) was purchased as a guaranteed-grade reagent and used without further purification. Silver nitrate solutions were prepared using water purified by the Millipore Simplicity UV system $(18.2 \mathrm{M} \Omega \mathrm{cm}$ at $25^{\circ} \mathrm{C}$ ). Antimicrobial studies were performed using a bacterial strain S. aureus ATCC 6538 purchased from ATCC (USA). Water for antibacterial experiments was prepared using the Millipore MilliQ ${ }^{\circledR}$ system.

\subsection{Preparation of $\mathrm{TiO}_{2}$ coatings}

The reactive magnetron sputtering of $\mathrm{TiO}_{2}$ coatings on silicon wafers $\left(\mathrm{S}_{\mathrm{Si}}\right)$ was carried out using the Plasmalab System 400 Sputter Tool (Oxford) in conditions reported in our previous paper [20]. In the typical procedure $\mathrm{Ti}$ was used as a target. The sputtering pressure was kept constant during the process at $5 \mathrm{mTorr}$ and a $1500 \mathrm{~W}$ magnetron power supply was used. The deposition was conducted in reactive discharges. Flow rates of argon and oxygen were maintained constant during the entire process and were equal to $25 \mathrm{~cm}^{3} \mathrm{~min}^{-1}$ flow rate of $\mathrm{Ar}$ and $35 \mathrm{~cm}^{3} \mathrm{~min}^{-1}$ flow rate of $\mathrm{O}_{2}$. The temperature was fixed at $22^{\circ} \mathrm{C}$ and the deposition time was set for 20 min. Resulting $\mathrm{TiO}_{2}$ coatings were calcined at $500^{\circ} \mathrm{C}$ for $2 \mathrm{~h}$ in order to obtain an anatase phase. The sample heating rate was $6.67^{\circ} \mathrm{C} \mathrm{min}^{-1}\left(100^{\circ} \mathrm{C} / 15 \mathrm{~min}\right)$. The coating thickness determined using a Horiba Jobin Yvon UVISEL spectroscopic ellipsometer operating in the range of 190-840 nm was $147 \mathrm{~nm}$.

\subsection{Growth of $\mathrm{AgNPs}$ on the $\mathrm{TiO}_{2}$ surface}

$\mathrm{TiO}_{2}$ coatings with AgNPs having a given diameter and surface density were prepared using the following $\mathrm{AgNO}_{3}$ solution concentrations and times of UV illuminations: $0.0 \mathrm{mM}$, $0 \mathrm{~min} ; 0.1 \mathrm{mM}, 30 \mathrm{~min} ; 1.0 \mathrm{mM}, 5 \mathrm{~min}$; and $1.0 \mathrm{mM}$, $30 \mathrm{~min}$. These types of coatings were arranged according to the increasing surface density of AgNPs and labelled as $\mathrm{S}_{0}=0\left(\right.$ pure $\left.\mathrm{TiO}_{2}\right), \mathrm{S}_{1}=3(\mathrm{AgNPs}) / \mu \mathrm{m}^{2}\left(\mathrm{TiO}_{2}\right), \mathrm{S}_{2}=11$ $(\mathrm{AgNPs}) / \mu \mathrm{m}^{2}\left(\mathrm{TiO}_{2}\right)$ and $\mathrm{S}_{3}=68(\mathrm{AgNPs}) / \mu \mathrm{m}^{2}\left(\mathrm{TiO}_{2}\right)$, respectively. $\mathrm{TiO}_{2}$ coatings were immersed into $2 \mathrm{ml}$ of $\mathrm{AgNO}_{3}$ solution prepared in deionized water and illuminated in UV light using a $2 \times 15 \mathrm{~W}$ UV-lamp (UV-Consulting Peschl, wavelength $\lambda=365 \mathrm{~nm}$ ). The power density measured on the sample level was $5 \mathrm{~mW} \mathrm{~cm}{ }^{-2}$. The power density declared by the producer was $2.3 \mathrm{~mW} \mathrm{~cm}^{-2}$. The distance between the illuminated coatings and the light source was fixed at $20 \mathrm{~cm}$ and the UV-rays were directed vertically to the surface coatings $\left(90^{\circ}\right)$.

\subsection{Evaluation of the antimicrobial activity of analysed coatings}

The antibacterial properties of $\mathrm{AgNPs} / \mathrm{TiO}_{2}$ coatings were determined according to Piwoński et al [16] using the Japanese Industrial Standard JIS Z 2801:2000. S. aureus ATCC 6538 was inoculated on Luria-Bertani (LB) broth and incubated at $37^{\circ} \mathrm{C}$ on a rotary shaker. S. aureus suspension including $1 \times 10^{5}$ colony forming units (CFU per ml) in 500fold diluted LB-broth was prepared for antibacterial tests. The diluted $S$. aureus inoculum was applied to $\mathrm{TiO}_{2}$ coatings with AgNPs having the size of $0.5 \mathrm{~cm} \times 0.5 \mathrm{~cm}$. Silicon wafers $\left(\mathrm{S}_{\mathrm{Si}}\right)$ were analysed as control samples. After the application of the bacterial suspension on the plates, each coating was covered with an aseptic film $(0.7 \mathrm{~cm} \times 0.7 \mathrm{~cm})$ and incubated in the moist chamber in the dark at $37^{\circ} \mathrm{C}$ for $24 \mathrm{~h}$. Next, the $S$. aureus suspensions were rinsed and serial dilutions were prepared in the phosphate buffer. Diluted bacterial suspensions were seeded on agar growth medium and incubated at $37^{\circ} \mathrm{C}$ for $24 \mathrm{~h}$. The antibacterial potential of tested plates was calculated as a percentage of $S$. aureus growth inhibition against control samples. All samples were tested in triplicate and individually analysed in four independent experiments.

\subsection{Detection of silver release from $\mathrm{AgNPs} / \mathrm{TiO}_{2}$ coatings}

The release of silver from $\mathrm{AgNPs} / \mathrm{TiO}_{2}$ coatings was monitored using atomic absorption spectrometry (AAS). The samples were immersed in a test-tube containing double 
distilled water for $24 \mathrm{~h}$ at $37^{\circ} \mathrm{C}$. The AAS experiments were carried out using a Varian SpectrAA 300 flame atomic absorption spectrophotometer with a hollow cathode lamp (PHOTRON PTY. LTD).

\subsection{S. aureus cell membrane permeability}

The bacterial cell membrane permeability was determined according to Zawadzka et al [13]. Briefly, after incubation on tested coatings $S$. aureus cells were washed with a PBS and stained with propidium iodide (PI) at $24^{\circ} \mathrm{C}$ for $15 \mathrm{~min}$ in the dark. Next, PI was washed from $S$. aureus suspension. After a spin the bacterial cells were suspended in $20 \mu \mathrm{l}$ PBS. Permeability of the $S$. aureus cell membrane was investigated using a confocal laser scanning microscope (LSM 510 Meta, Zeiss) with an attached Axiovert 200M (Zeiss) inverted fluorescence microscope equipped with a Plan-Apochromat objective (63/1.25 Oil). To determine the percentage of bacterial cells with a destroyed membrane, at least 20 independent images were analysed using AxioVision Software (Zeiss), the ratio of the PI fluorescence area to the $S$. aureus cells area was calculated.

\subsection{SEM imaging and EDS analysis}

SEM imaging of $\mathrm{TiO}_{2}$ and $\mathrm{AgNPs} / \mathrm{TiO}_{2}$ coatings as well as $S$. aureus cells were performed using a Schottky field-emission scanning electron microscope (FESEM), FEI apparatus, model Nova NanoSEM 450. Images were acquired in an immersion mode using a through lens detector (TLD) at typical magnification of $80,000 \times$. The AgNPs size distribution plots were calculated by analysing the AgNPs diameters obtained from SEM images on the basis of at least 100 particles. However, the mean value of the AgNPs size was calculated using the selected size ranges excluding the smallest and the largest NPs. These ranges are visible on the size distribution plots in grey areas.

Visualization of $S$. aureus cells after contact with investigated coatings was also performed with the use of SEM microscopy according to the following procedure. S. aureus cells were suspended in cold gluataraldehyde and incubated for $2 \mathrm{~h}$ in $4^{\circ} \mathrm{C}$ after the incubation on $\mathrm{Si}, \mathrm{TiO}_{2}$ and AgNPs/ $\mathrm{TiO}_{2}$ coatings. Next, bacterial cells were washed thrice with PBS and dehydrated in series ethanol solutions (30, 50, 80 and $90 \%$ ) for $15 \mathrm{~min}$ each. Subsequently, dried bacterial cells were coated with carbon and visualized in SEM.

The elemental analysis of $\mathrm{AgNPs} / \mathrm{TiO}_{2}$ coatings was performed using an EDAX Roentgen spectrometer (EDS) having an Octane Pro Silicon Drift Detector (SDD) with a high area active surface $\left(60 \mathrm{~mm}^{2}\right)$.

\section{Results and discussion}

\subsection{Characterization of $\mathrm{TiO}_{2}$ and $\mathrm{AgNPs} / \mathrm{TiO}_{2}$ coatings}

The surface topography analysis of $\mathrm{TiO}_{2}$ and $\mathrm{AgNPs} / \mathrm{TiO}_{2}$ coatings before and after antibacterial tests was performed with the use of SEM. Table 1 presents SEM images of the $\mathrm{TiO}_{2}$ control surface $\left(\mathrm{S}_{0}\right)$ and AgNPs having various size and surface density $\left(S_{1}-S_{3}\right)$. The size of AgNPs (and their surface density) obtained in our experiments measured by SEM were in the range from $d=14 \pm 7$ to $42 \pm 14 \mathrm{~nm}$ for samples $S_{3}$ and $S_{2}$ (table 2). The number of nanoparticles was in the range from $n=11$ to $68 \mathrm{AgNPs} / \mu \mathrm{m}^{2}$. In the case of a coating labelled as $\mathrm{S}_{1}$, only few NPs were found on the surface area of $1 \mu^{2}$ but their sizes varied from 46 to $240 \mathrm{~nm}$.

Changes in the surface topography were noticeable after antibacterial tests. SEM observations revealed partial decomposition of AgNPs leading to changes in their size and geometry (table 1). Moreover, an increase in the number of smaller pieces being the products of their decomposition after biological tests was found. This phenomenon can be attributed to the interactions between the $\mathrm{AgNPs} / \mathrm{TiO}_{2}$ coatings during the contact with bactericidal medium and/or $S$. aureus cell membranes combined with the release of silver.

Table 3 presents the distribution of AgNPs sizes after antibacterial tests. It was found that the size of AgNPs after antimicrobial investigations was reduced to even half the initial size of AgNPs. Moreover, the number of small particles being the products of erosion of large AgNPs in their nearest surroundings was much higher than before the tests, in the case of a $S_{1}$ sample reached its extreme of almost two orders of magnitude. The appearance of smaller particles maintained the rate of silver release.

In order to determine the composition of coating constituents, elemental analysis of $\mathrm{AgNPs} / \mathrm{TiO}_{2}$ composites was performed using SEM-EDS spectrometry. Table 4 presents the spectrum and maps of elements found on the surface of the $\mathrm{S}_{3}$ coating. Since the $\mathrm{TiO}_{2}$ coating in the EDS analysis was quite thin, the main peak coming from silicon (the substrate) is visible on the spectrum. However, other elements like titanium and silver were also detected and their presence was confirmed. The distribution of the mentioned elements is well visible on the individual EDS maps of oxygen, silicon, silver and titanium. Images gathered in table 4 overlay the topography image indicating that the objects visible in topographical images as large grains (NPs) are built of silver. The atomic composition presented in table 5 also gives some information about the number of elements in the coatings. However, due to the deep dispersion of electrons in the specimen, much greater than the thickness of the coating, the SEM-EDS analysis have a purely qualitative meaning. The results of the SEM-EDS analysis are in good agreement with XPS measurements reported in our previous work indicating the presence of stoichiometric $\mathrm{TiO}_{2}$ and metallic silver on the coatings [23].

\subsection{Antimicrobial activity and durability of the $\mathrm{TiO}_{2}$ coatings with AgNPs}

The concept of using materials with immobilized AgNPs as antimicrobial agents is of considerable interest. Immobilized 
Table 1. SEM images of $\mathrm{TiO}_{2}$ and $\mathrm{AgNPs} / \mathrm{TiO}_{2}$ coatings before and after biological tests.

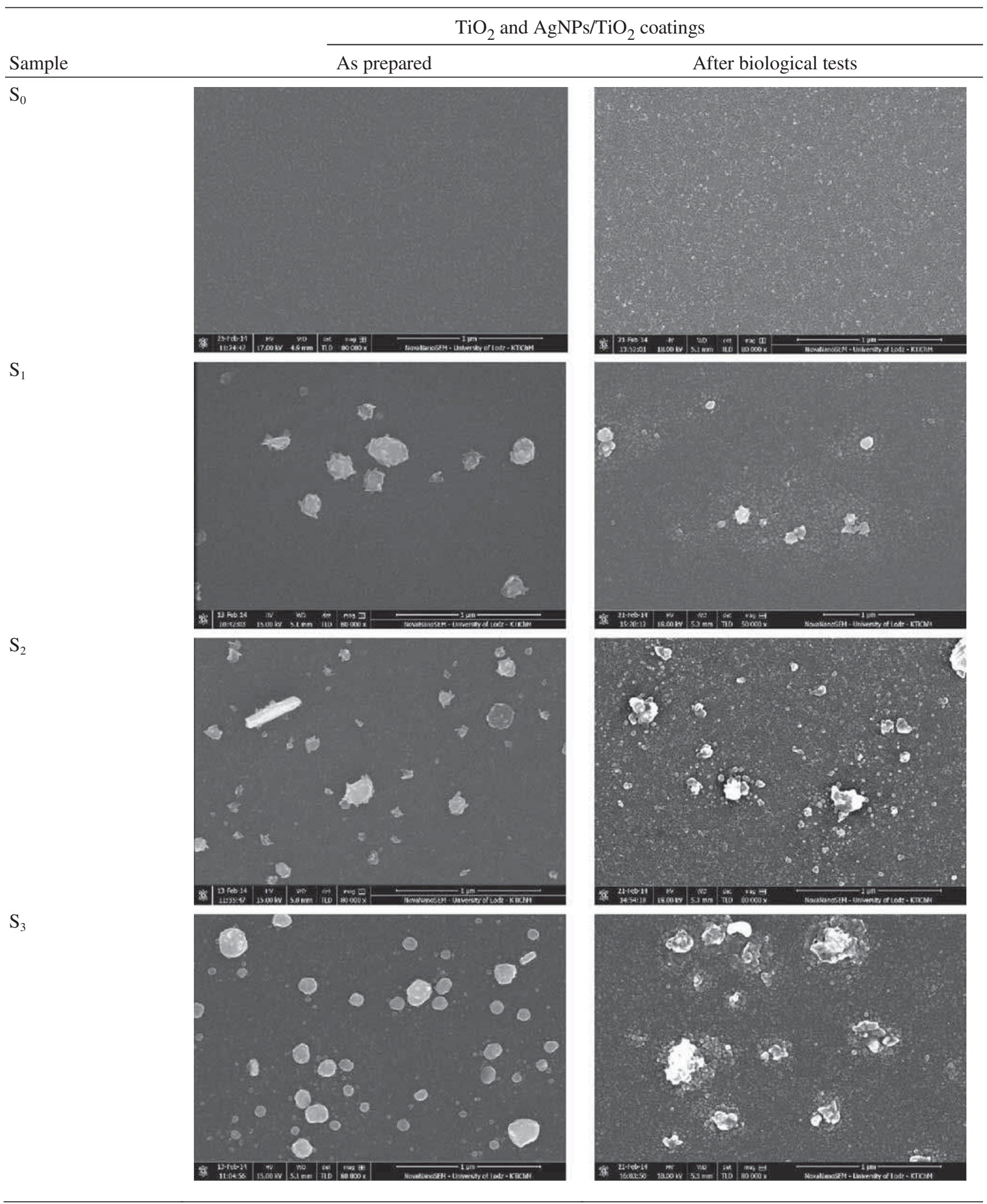

AgNPs demonstrate higher stability than colloidal AgNPs due to their protection from oxidation and aggregation, which makes their multiple use possible [20]. Many researchers described excellent antimicrobial activity of immobilized AgNPs against different microorganisms $[10,13,15,16]$. There is still debate on the mode of antibacterial action of AgNPs. 
Table 2. Size distribution and surface density of as-prepared $\mathrm{AgNPs}$ on $\mathrm{TiO}_{2}$ calculated from $\mathrm{SEM}$ measurements.

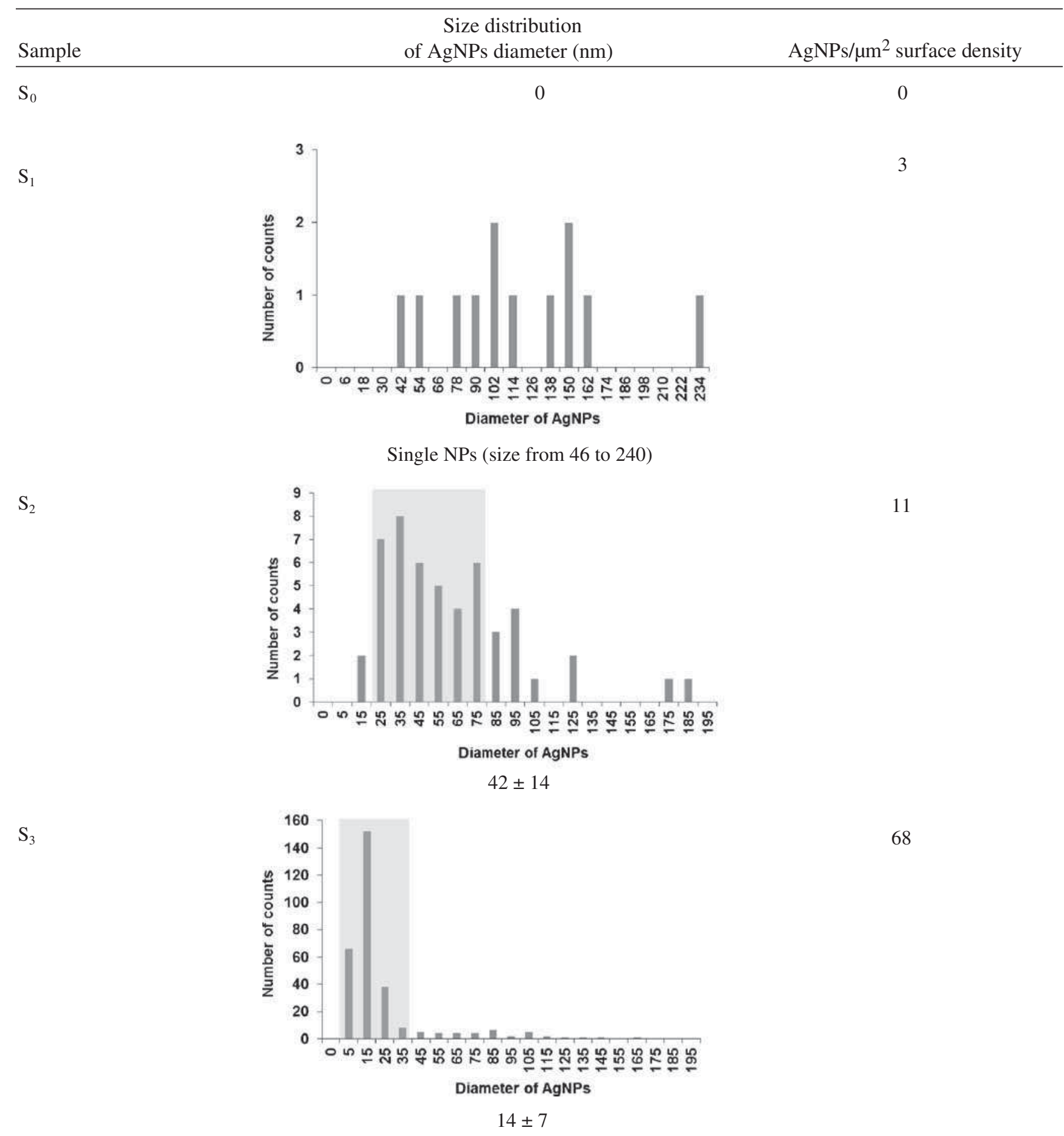

In recent times, many factors determining their high bactericidal potential and the mechanism of antibacterial action have been studied. Initially, the size of AgNPs was described as an agent deciding about their high potential against microorganisms [7,11,12]. Panacek et al [11] showed that the highest toxicity toward drug-resistant bacteria was exhibited by the smallest of tested AgNPs [11]. Similar results were obtained in the study of AgNPs having the sizes in the range $1-100 \mathrm{~nm}$, where the strongest antibacterial properties were demonstrated by NPs with a small diameter 1-10 nm [12]. Piwoński et al [16] showed interdependence between the bioactivity of AgNPs grown on titania coatings and the diameter/surface density. Contact killing and silver ion-mediated killing were proposed as two main mechanisms of bactericidal activity of AgNPs [20]. Therefore researchers analysed the relationship between the size of AgNPs, the concentration of released silver and their antibacterial activity. Xiu et al [7] suggested that the high antimicrobial potential of small 
Table 3. Size distribution and surface density of $\mathrm{AgNPs} / \mathrm{TiO}_{2}$ coatings after biological tests.

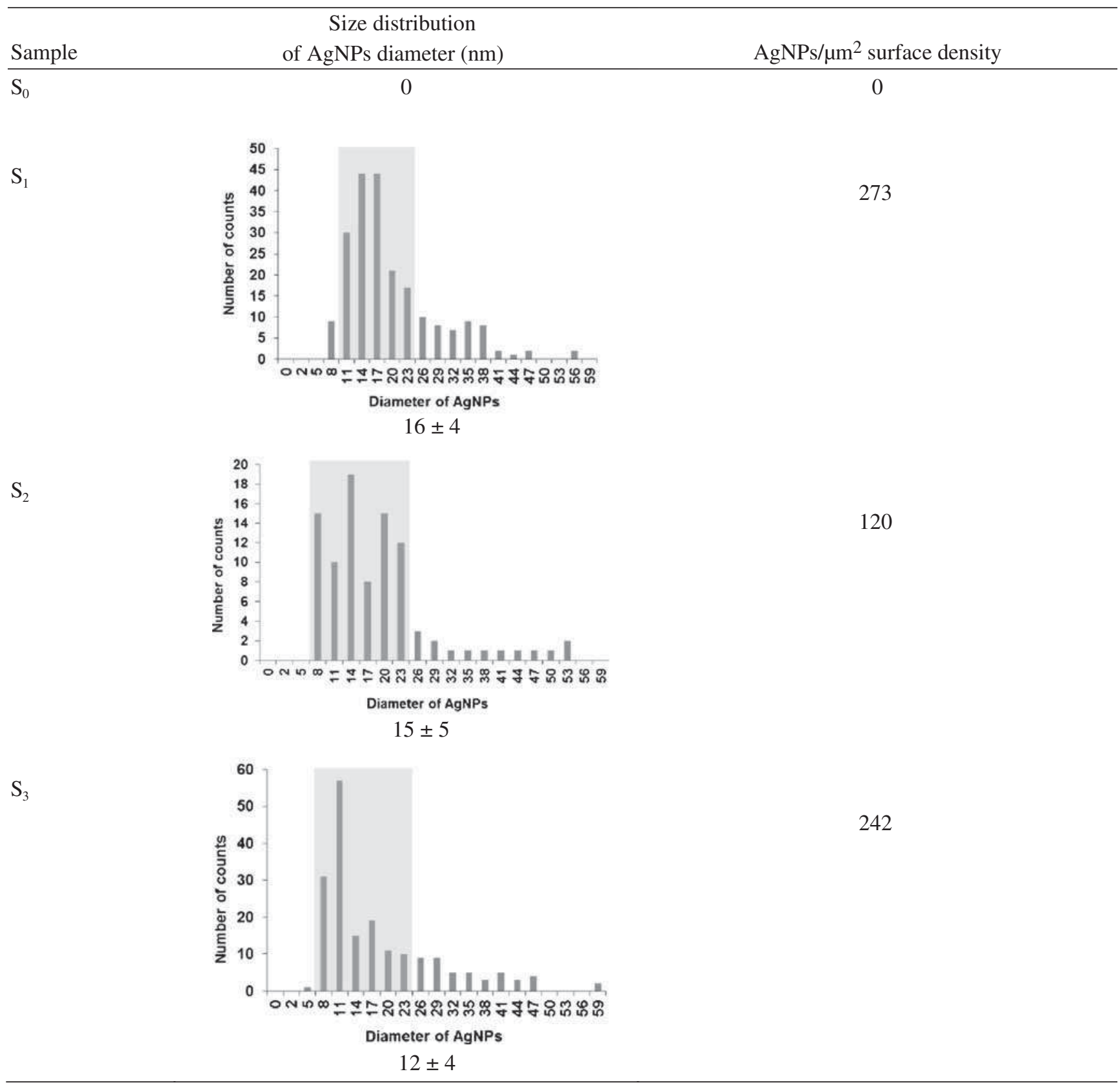

AgNPs could result from their larger surface area and faster $\mathrm{Ag}^{+}$ions release compared to AgNPs of a large size. In this paper, the antibacterial activity of magnetron sputtered $\mathrm{TiO}_{2}$ coatings covered by AgNPs with different sizes and surfaces density was investigated. The antimicrobial properties of $\mathrm{AgNPs} / \mathrm{TiO}_{2}$ coatings were studied against Gram-positive bacteria $S$. aureus, as shown in figure 1. The $S_{2}$ and $S_{3}$ coatings showed strong antimicrobial potential against tested bacteria. The strongest activity against $S$. aureus was demonstrated by $\mathrm{S}_{3}$ samples, which caused $89.9 \%$ inhibition of bacterial growth. Sample $S_{3}$ was characterized by the smallest size of $\operatorname{AgNPs}(d=14 \pm 7 \mathrm{~nm})$ and the highest nanoparticle density $\left(n=68 \mathrm{AgNPs} / \mu \mathrm{m}^{2}\right)$. For the $S_{2}$ sample the reduction in the viability of bacteria was $80.3 \%$ of control.
The size of AgNPs and their surface density for this sample were $d=42 \pm 14 \mathrm{~nm}$ and $n=11 \mathrm{AgNPs} / \mu \mathrm{m}^{2}$, respectively. The weakest antimicrobial activity was showed by $S_{1}$ coatings. For $\mathrm{S}_{1}$ plates the $S$. aureus growth inhibition reached a value of $22.9 \%$. The sizes of AgNPs for the $S_{1}$ sample were considerably different and their diameter varied from 46 to $240 \mathrm{~nm}$. It was observed that in the case of $\mathrm{TiO}_{2}$ coatings without AgNPs, the inhibition of bacterial growth compared to control samples $\mathrm{S}_{\mathrm{Si}}$ (silicon wafer) was 6\%. Moreover, the release of silver from tested $\mathrm{AgNPs} / \mathrm{TiO}_{2}$ coatings was determined. The AAS was used to analyse the silver released from the tested $\mathrm{AgNP} / \mathrm{TiO}_{2}$ plates. The interdependence between the inhibition of $S$. aureus growth and the amount of released silver was proved-figure 1 . The bacterial growth reduction 
Table 4. SEM-EDS analysis (maps of elements and spectrum) of the AgNPs/ $/ \mathrm{TiO}_{2}$ coating $\left(\mathrm{S}_{3}\right)$.
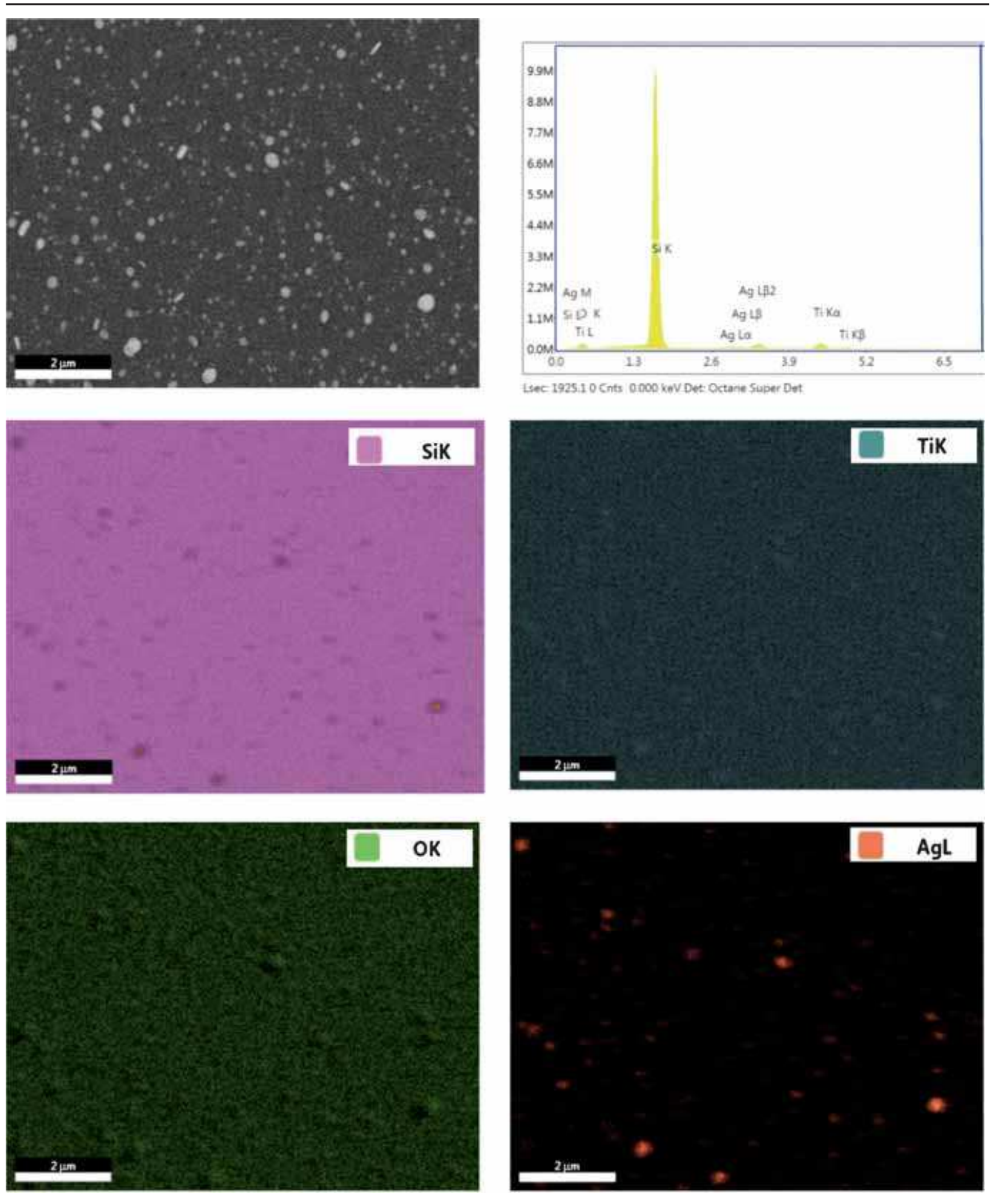

was the lowest for $S_{1}$ sample exhibiting the smallest amount of released silver $(0.107 \mathrm{ppm})$. For $\mathrm{S}_{2}$ and $\mathrm{S}_{3}$ samples, which caused 80.3 and $89.9 \%$ inhibition of bacterial growth, the concentration of released silver were 0.224 and 0.234 $\mathrm{ppm}$, respectively. The silver concentration released from $\mathrm{AgNPs} / \mathrm{TiO}_{2}$ coatings correlated with their antibacterial 
Table 5. SEM-EDS analysis of $\mathrm{AgNPs} / \mathrm{TiO}_{2}$ coating $\left(\mathrm{S}_{3}\right)$.

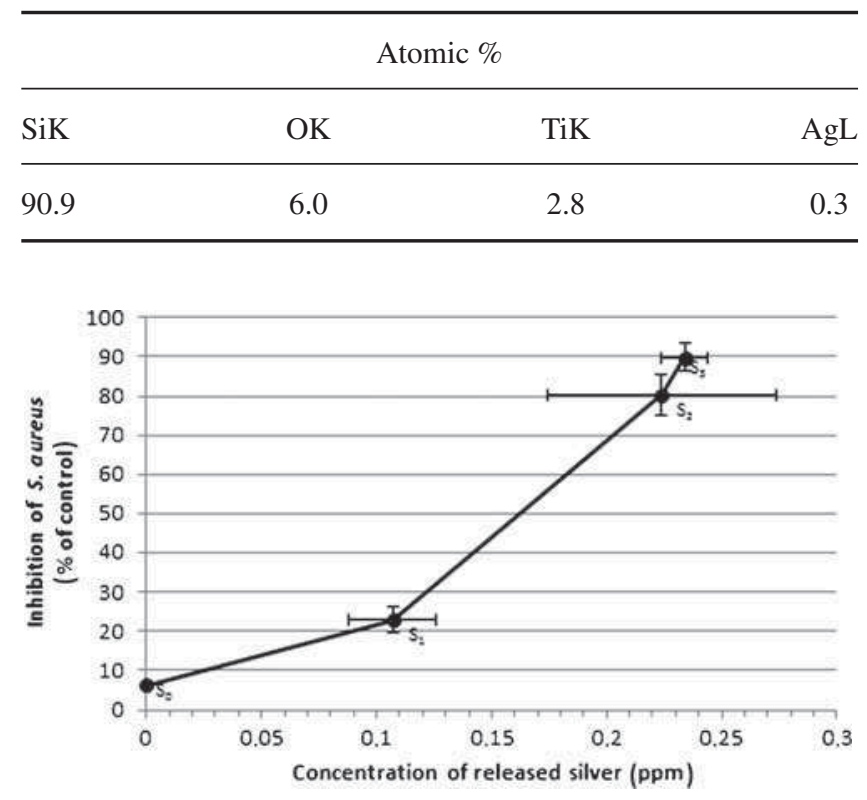

Figure 1. Inhibition of $S$. aureus growth by silver nanoparticles grown on $\mathrm{TiO}_{2}$ coatings ( $\%$ of control) vs. the concentration of released silver (ppm).

properties. The best antibacterial activity was observed for the $S_{3}$ sample with the largest amount of released silver ions. The $S_{1}$ sample with the lowest concentration of released silver exhibited the lowest inhibition of $S$. aureus. It was observed that an increase in the silver concentration considerably improved the antibacterial activity of tested coatings.

The mechanisms of the antibacterial action of AgNPs is an object of other studies [24-28]. Researchers pay attention to the role of silver ions released from AgNPs in the inhibition of bacterial growth. Silver ions can disrupt the operation of sulphur-containing proteins in the cell wall. Moreover, interactions of silver ions with thiol groups of enzymes have effect on the inactivation of proton motive force and respiration [6]. Pal et al [29] suggested that silver ions inhibit the action of respiratory chain enzymes and further reactive oxygen forms generations and in consequence cause damage to the bacterial cell. In this paper, it was demonstrated that the increased concentration of released silver contributes to higher efficiency of tested AgNPs coatings against $S$. aureus. These results explain the antimicrobial mechanism of magnetron sputtered $\mathrm{TiO}_{2}$ coatings with AgNPs.

In order to determine the stability and durability of the tested coatings, antimicrobial activity studies were performed in four independent experiments, each time in triplicate (table 6). Similar results concerning the antibacterial activity of tested coatings were observed each time in spite of changes in their surface topography visualized in SEM. It seems that it did not significantly affect the antimicrobial activity of the coatings. The differences in the level of $S$. aureus growth inhibition in all experiments for each sample were neglible, which indicates their great antibacterial stability and durability.
Table 6. Antimicrobial stability and durability of $\mathrm{AgNPs} / \mathrm{TiO}_{2}$ coatings.

\begin{tabular}{lcccc}
\hline & \multicolumn{4}{c}{ Experiment } \\
\cline { 2 - 5 } Sample & I & II & III & IV \\
\hline $\mathrm{S}_{\mathrm{Si}}$ & 0 & 0 & 0 & 0 \\
$\mathrm{~S}_{0}$ & 9.3 & 3.2 & 5.5 & 6.9 \\
$\mathrm{~S}_{1}$ & 16.0 & 29.2 & 24.3 & 22.0 \\
$\mathrm{~S}_{2}$ & 71.7 & 88.4 & 81.4 & 79.8 \\
$\mathrm{~S}_{3}$ & 92.5 & 88.7 & 90.3 & 87.9 \\
\hline
\end{tabular}

\subsection{Mechanism of action of AgNPs grown on $\mathrm{TiO}_{2}$ coatings}

Propidium iodide (PI) staining and confocal microscopy were used to explain the mechanism of $\mathrm{AgNPs} / \mathrm{TiO}_{2}$ coatings bactericidal activity. PI staining allows determining $S$. aureus mortality, because PI penetrates only into dead cells with damaged a membrane. Figure 2 presents the confocal microscopy images of $S$. aureus cells after the treatment with AgNPs and PI staining, where red-stained cells were visible. The intensity of the fluorescence was analysed for representative images (table 7; right panel). The intensity diagrams show the differences between the samples. The most intense peaks for samples $S_{2}$ and $S_{3}$ were observed but for sample $\mathrm{S}_{\mathrm{Si}}$ the intensity was at the background level. The results obtained from the diagrams enable the calculations of the mortality of $S$. aureus cells. The calculations presented in table 7 (left panel) show, that for samples $\mathrm{S}_{\mathrm{Si}}, \mathrm{S}_{0}$ and $\mathrm{S}_{1}$ the mortality reached $0,4.58$ and $23.75 \%$, respectively. In the case of $S_{2}$ and $S_{3}$ samples, we noted 50.25 and $74.77 \%$ of $S$. aureus dead cells, whereas the inhibition of $S$. aureus growth was 80.3 and $89.9 \%$, respectively (figure 1). As shown in figure $2 \mathrm{a}$ and table 7 , in the control samples the bacterial cell walls were not disrupted. The confocal microscopy analysis revealed that mortality rates of $S$. aureus were lower than the inhibition of the microorganism growth. Differences between the inhibition of bacterial growth and percentage of dead S. aureus cells suggest a multiple mechanism of antimicrobial activity of the tested coatings. Better results of S. aureus growth inhibition were observed because the bacteria were incapable of cells division after their re-cultivation on agar plates despite maintaining the integrity of the bacterial cell membrane. It could cause DNA damage, block bacterial cell respiration, mitochondrial dysfunction or protein peroxidation by AgNPs and/or silver ions. In order to evaluate the mechanism of antibacterial activity of tested coatings, the $S$. aureus cells morphology after incubation on the AgNPs $/ \mathrm{TiO}_{2}$ and control plates was examined by SEM (figure 3). S. aureus cells after contact with AgNPs had apparent damage compared to bacteria incubated on control plates which had normal and regular shape, the cells after the treatment with AgNPs were misshapen and ridged (figure $3 \mathrm{~b} 1$ and $\mathrm{b} 2$ ). The observed changes of the membrane structure indicate leakage of the cytosolic content and bacterial cell lysis. SEM images suggested the bactericidal action 


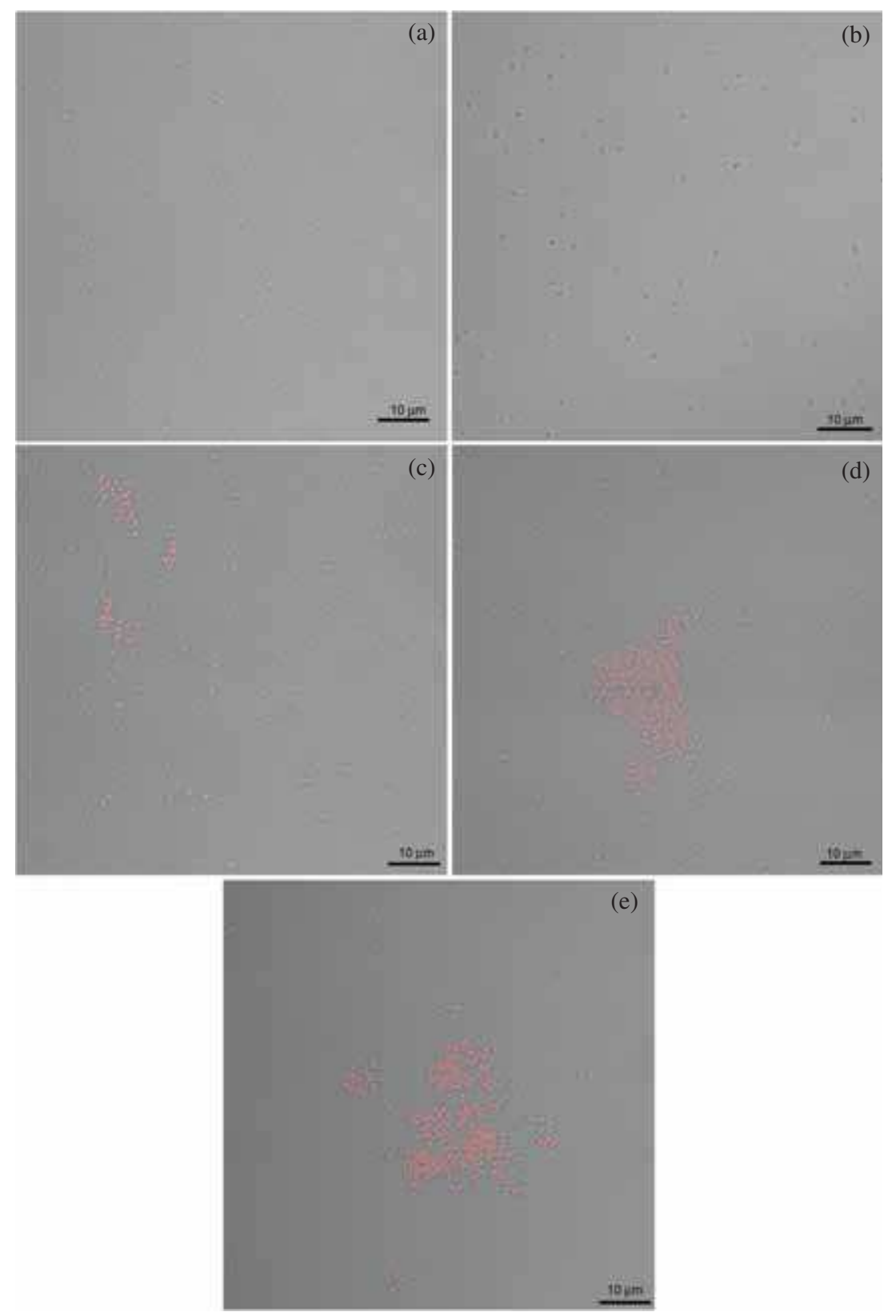

Figure 2. Membrane permeability of $S$. aureus cell after the treatment with tested samples (a) $\mathrm{S}_{\mathrm{Si}}$, (b) $\mathrm{S}_{0}$, (c) $\mathrm{S}_{1}$, (d) $\mathrm{S}_{2}$ and (e) $\mathrm{S}_{3}$.

by direct contact of bacteria with AgNPs immobilized on the tested coatings.

Damage to a bacterial membrane as a result of AgNPs adhesion to the surface of a microbial cell or damage to DNA by AgNPs penetrating into the cells of bacteria were proposed as another mechanism of antibacterial action of AgNPs. Cao et al investigated biological action of AgNPs embedded in titanium controlled by micro-galvanic effect and showed high antibacterial potential of tested composites. The authors observed the death of microorganisms as a result of the disruption of the bacterial cell membrane after contact with AgNPs [30]. Tian et al [28] investigated the antibacterial activity of $\mathrm{TiO}_{2}$ coatings modified by iron NPs. The authors observed destruction of $S$. aureus cells after the treatment with tested coatings. In another study the outer membrane of $E$. coli after contact with silver was showed. Damage to bacterial cells after the treatment with mesoporous anatase $\mathrm{Ag} / \mathrm{TiO}_{2}$ composites was visualized in FE-SEM images [8]. In our investigations we found identical morphological changes in bacterial cells (figure 3). The consequence of the AgNPs contact with the bacterial cells surface was the formation of pores and holes and subsequently cell lysis. SEM images indicate that $S$. aureus cells were damaged as a result of the adherence of bacterial cells to AgNPs. Considering the antimicrobial activity of $\mathrm{AgNPs} / \mathrm{TiO}_{2}$ coatings and the permeability of the $S$. aureus cell membrane, it may be indicated 
Table 7. Mortality of S. aureus (\%) and the intensity diagrams of propidium iodide stained bacterial cells after incubation on coatings without and with AgNPs.

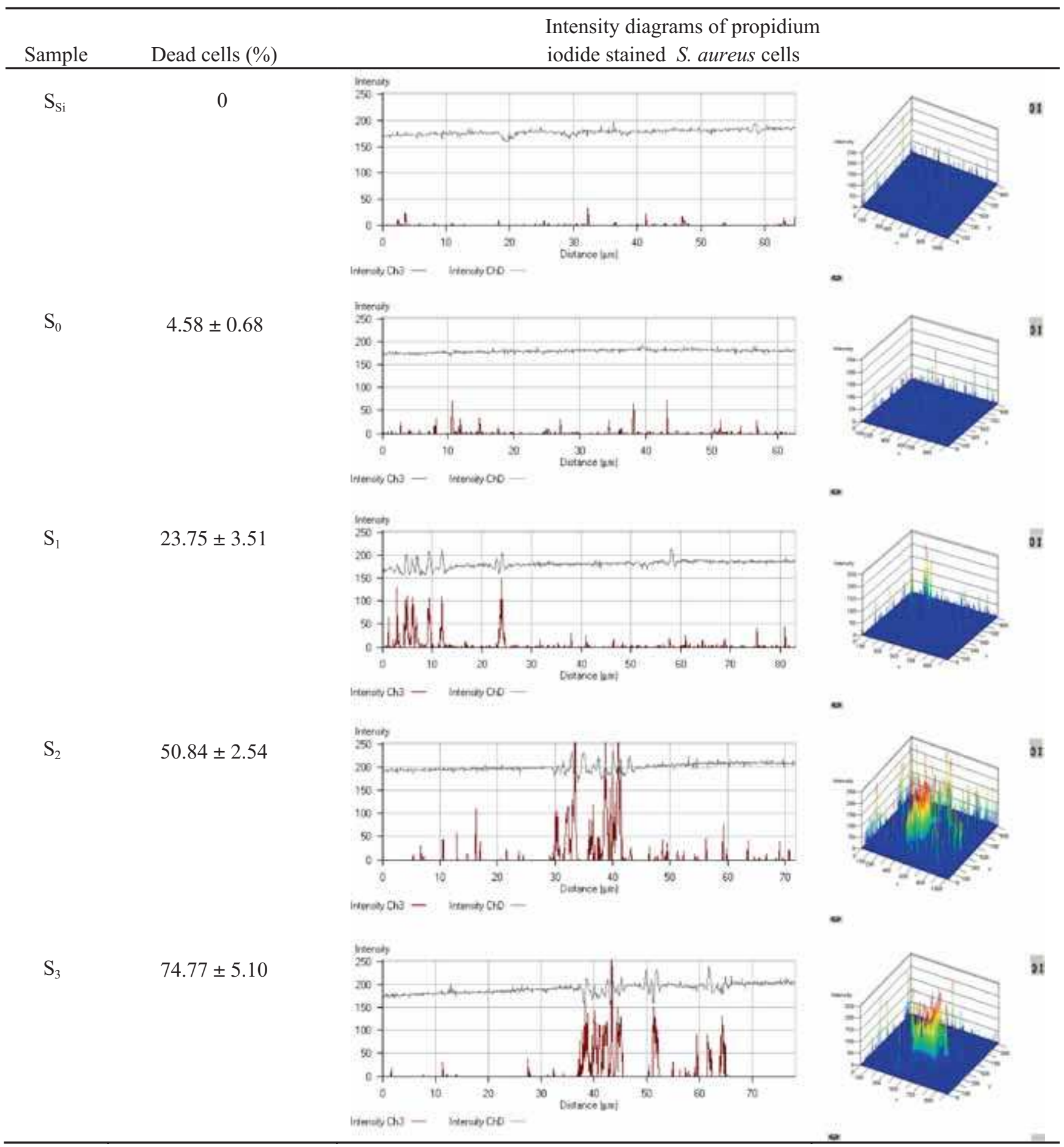

that small AgNPs or $\mathrm{Ag}^{+}$ions penetrate through the bacterial membrane causing damage to DNA and disabling cell division after re-cultivation on agar plates.

\section{Conclusions}

AgNPs grown on magnetron sputtered $\mathrm{TiO}_{2}$ coatings showed strong antibacterial properties against the $S$. aureus strain.
Direct relationship between the concentration of released silver and antibacterial activity of AgNPs has been shown. All tested coatings also exhibited high antimicrobial stability and durability in spite of the observed changes in their topography, which is crucial for practical antibacterial application. The mechanisms of action against $S$. aureus bacteria of tested $\mathrm{AgNPs} / \mathrm{TiO}_{2}$ plates using confocal microscopy and SEM were proposed. The obtained results point to for 

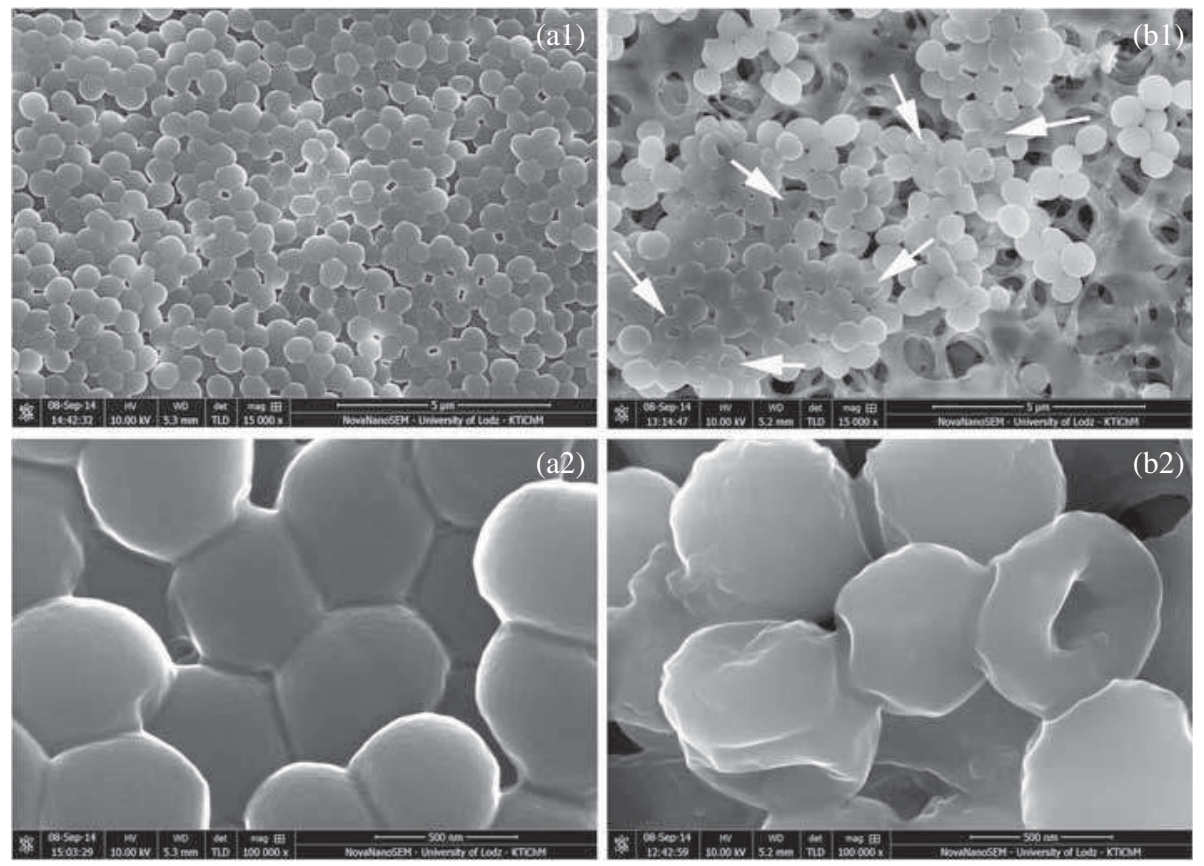

Figure 3. SEM images of $S$. aureus for $24 \mathrm{~h}$ incubation on the control sample (a1, a2) and on the $S_{3}$ sample with AgNPs (b1, b2).

three pathways of the antibacterial activity of tested coatings. Silver released from AgNPs may interact with enzymes in the bacterial cell membranes and disturb their functionality or penetrate into the bacterial cell and damage DNA. SEM microscopy was used to analyse the surfaces topography of as prepared and after biological tests $\mathrm{TiO}_{2}$ and $\mathrm{AgNPs} / \mathrm{TiO}_{2}$ coatings as well as to observe morphological changes in S. aureus cells. The hole formation in the bacterial cell may indicate direct contact of AgNPs with bacterial cells and disintegration of the cell walls, which could cause $S$. aureus cells lysis.

\section{Acknowledgement}

This work was supported by the Ministry of Science and Higher Education of Poland (grant number N N507 497538).

\section{References}

[1] Cao H, Liu X, Meng F and Chu P K 2010 Wiley Interdiscip. Rev. Nanomed. Nanobiotechnol. 2670

[2] Siddiqui M R H, Adil S F, Assal M E, Ali R and Al-Warthan A 2013 Asian J. Chem. 253405

[3] Kholoud M M, El-Nour A, Eftaiha A A, Al-Warthan A and Ammar R A A 2010 Arab. J. Chem. 3135

[4] Ruparelia J P, Chatterjee A K, Duttagupta S P and Mukherji S 2008 Acta Biomater. 4707

[5] Satiriou G A and Pratsinis S E 2010 Environ. Sci. Technol. 44 5649
[6] Reidy B, Haase A, Luch A, Dawson K A and Lynch I 2013 Materials 62295

[7] Xiu Z M, Zhang Q B, Puppala H L, Colvin V L and Alvarez P J 2012 Nano Lett. 124271

[8] Liu Y, Wang X, Yang F and Yang X 2008 Microporous Mesoporous Mater. 114431

[9] Perkas N, Lipovsky A, Amirian G, Nitzan Y and Gedanken A 2013 J. Mater. Chem. B 15309

[10] Necula B S, Fratila-Apachitei L E, Zaat S A, Apachitei I and Duszczyk J 2009 Acta Biomater. 53573

[11] Panacek A, Kvítek L, Prucek R, Kolar M, Vecerova R, Pizúrova N, Sharma VK, Nevecna T and Zboril R 2006 J. Phys. Chem. B 11016248

[12] Morones J R, Elechiguerra J L, Camacho A, Holt K, Kouri J B, Ramírez J T and Yacaman M J 2005 Nanotechnology 16 2346

[13] Zawadzka K, Kądzioła K, Felczak A, Wrońska N, Piwoński I, Kisielewska A and Lisowska K 2014 New J. Chem. 383275

[14] Zhang H and Chen G 2009 Environ. Sci. Technol. 432905

[15] Zhang Q, Sun C, Zhao Q, Zhou S, Hu X and Chen P 2010 Environ. Sci. Technol. 448270

[16] Piwoński I, Kądzioła K, Kisielewska A, Soliwoda K, Wolszczak M, Lisowska K, Wrońska N and Felczak A 2011 Appl. Surf. Sci. 2577076

[17] Meng F and Lu F 2010 J. Alloys Compd. 501154

[18] Meng F and Sun Z 2009 Mater. Chem. Phys. 118349

[19] Marambio-Jones C and Hoek E M V 2010 J. Nanopart. Res. 121531

[20] Agnihotri S, Mukherji S and Mukherji S 2013 Nanoscale 5 7328 
[21] Bien J, Sokolova O and Bozko P 2011 J. Pathogens 20111

[22] Bartlett J G 2008 Top HIV Med. 16151

[23] Kądzioła K, Piwoński I, Kisielewska A, Szczukocki D, Krawczyk B and Sielski J 2014 Appl. Surf. Sci. 288 503

[24] Li W R, Xie X B, Shi Q S, Zeng H Y, Ou-Yang Y S and Chen Y B 2010 Appl. Microbiol. Biotechnol. 851115

[25] Li Q, Mahendra S, Lyon D Y, Brunet L, Liga M V, Li D and Alvarez P J J 2008 Water Res. 424591
[26] Prabhu S and Poulose E K 2012 Int. Nano Lett. 232

[27] Kora A J and Arunachalam J 2011 World J. Microbiol. Biotechnol. 271209

[28] Tian Y, Cao H, Qiao Y, Meng F and Liu F 2014 Acta Biomater. 104505

[29] Pal S, Tak Y K and Song J M 2007 Appl. Environ. Microb. 73 1712

[30] Cao H, Liu X, Meng F and Chu P K 2011 Biomaterials 32 693 